\title{
Ecological and chemical characteristics of small river Arguzikha (Zeya-Bureya plain, Russia)
}

\author{
Antonina Pakusina ${ }^{1}$ and Tatyana Platonova $^{2}$ \\ ${ }^{1}$ Far Eastern State Agrarian University ,86, Politeknicheskaya Str., Blagoveschensk, Russia \\ ${ }^{2}$ Amur State University, 21, Ignatievskoe St., Blagoveshchensk, Russia
}

\begin{abstract}
The article considers the results of research from 2015 to 2019 on the study of hydrochemical indicators and the content of heavy metals in the ecosystem components of the small Arguzikha river, a left-Bank tributary of the Amur river (water, bottom sediments, macrophytes, birds ' feathers). High oxygen content in the water $\left(8.8-15.9 \mathrm{mgO}_{2} / \mathrm{dm}^{3}\right)$ and high $\mathrm{BOD}_{5}$ values $\left(6-12 \mathrm{mgO}_{2} / \mathrm{dm}^{3}\right)$ in the middle and lower reaches of the Arguzikha river indicate the process of eutrophication. The value of permanganate oxidability $\left(6.8-15.5 \mathrm{mgO} / \mathrm{dm}^{3}\right)$ characterizes the high content of organic substances in water. In the spring, nitrate nitrogen (3.45$6.39 \mathrm{mgN}-\mathrm{NO}_{3}{ }^{-} / \mathrm{dm}^{3}$ ) was found in the water of the Arguzikha river, which had a pyrogenic origin. In the summer the rainy season was dominated by ammonium nitrogen $\left(2.34 \mathrm{mgN}-\mathrm{NH}_{4}{ }^{+} / \mathrm{dm}^{3}\right)$. The high content of total phosphorus $\left(0.337-0.609 \mathrm{mg} / \mathrm{dm}^{3}\right)$ in the river water was in the spring. In the spring of 2015, the concentration of lead in the lower reaches of the river reached $6.36 \mu \mathrm{g} / \mathrm{dm}^{3}$, during the subsequent time, the lead content in the Arguzikha water was less than the MPC. Toxic concentrations of lead $(>30 \mathrm{mg} / \mathrm{kg}$ ) and manganese (>300 mg/kg) were found in macrophytes of Nymphoides peltata and Myriophyllum spicatum. In the feathers of waterfowl of the Arguzikha river the content of heavy metals decreases in a row $\mathrm{Fe}>\mathrm{Zn}>\mathrm{Cu}>\mathrm{Pb}>\mathrm{Mn}>\mathrm{Cr}>\mathrm{Ni}>\mathrm{Co}>\mathrm{Cd}$. The feathers of Anas acuta and Anas querquedula contained $\mathrm{Pb} 17.7 \mathrm{mg} / \mathrm{kg}$ and $22.2 \mathrm{mg} / \mathrm{kg}, \mathrm{Cd} 0.15$ $\mathrm{mg} / \mathrm{kg}$ and $0.08 \mathrm{mg} / \mathrm{kg}$, respectively.
\end{abstract}

\section{Introduction}

The natural landscapes of the Zeya-Bureya plain have changed as a result of human activity. Here is the largest agro-industrial complex in the Russian far East, animal husbandry is developing, and huge areas of land are plowed for growing grain crops, soybeans, and rapeseed. Such changes have negatively affected the biodiversity of biocenoses. The use of mineral fertilizers and herbicides contributed to the accumulation of heavy metals in the soil [1]. During floods and inundations, heavy metals entered the water of small rivers from the surface layers of the soil. The quality of small rivers deteriorated due to the introduction of organic substances, heavy metals, nitrogen and phosphorus compounds into the water from the soil. Mass plowing of land in the floodplains of small rivers of the Zeya-Bureya plain, deforestation, construction of reservoirs, and application of fertilizers to the soil contributed to changes in the water quality of small rivers $[2,3]$. Macrophytes enrich water with oxygen during photosynthesis, participate in the process of 
self-purification of small rivers, and extract heavy metals from sediments and water. Heavy metals can have a toxic effect on macrophytes [4]. Macrophytes are sensitive indicators of anthropogenic pollution [5, 6]. Higher water plants serve as habitat and food for birds [3]. Small rivers of the Zeya-Bureya plain are tributaries of the Amur river, the river banks are usually swampy. The preserved wetlands are home to rare and endangered bird species that need protection. Accumulation of heavy metals in the habitat has a negative impact on birds, contributes to disease and death of birds [7]. Pollution of the environment with heavy metals leads to a violation of the reproductive function of birds and a decrease in the growth rate of Chicks [8]. All this has determined the importance of studying the accumulation of heavy metals in the components of the ecosystem of small rivers. The aim of this work is to study the ecological state of the Arguzikha river based on hydrochemical indicators and the content of heavy metals in water, river bottom sediments, macrophytes and bird feathers.

\section{Object and methods of research}

The object of study was water, sediments, rivers Arguzikha, macrophytes and bird feathers. The area where the research was conducted is the small Arguzikha river, a left tributary of the Amur river. The Arguzikha river flows into the Amur river $1892 \mathrm{~km}$ from the mouth, the length of the watercourse is $47 \mathrm{~km}$. Samples were collected in four sections: I - the river

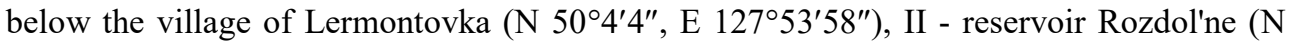
$50^{\circ} 1^{\prime} 1^{\prime \prime}$, E $\left.127^{\circ} 50^{\prime} 37^{\prime \prime}\right)$, III - the river below the village of Kuropatino (N 49 $58^{\prime} 56^{\prime \prime}, \mathrm{E}$

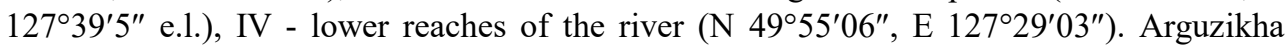
river flows through agricultural landscape of southern Zeya-Bureya plain. The river flows through an open space, only in the lower reaches of the river the banks are overgrown with shrubs and trees, mainly willows. For a long distance, the river is completely blocked from above by a carpet of floating plants, mainly reeds. Fires easily move from one Bank to the other, destroying ground vegetation. In the lower reaches of the Arguzikha river there are unique wetlands of the Muravyevsky reserve, where about 300 species of birds live, including those that are under protection - the red-crowned crane, the Oriental stork, the hooded crane and the Daurian white-naped crane. In the reeds of the river Arguzikha, which sometimes completely cover the water surface to nest Schrenck's Bittern, Brown-cheeked Rail, Oriental Reed-warbler, Northern Reed Bunting. On Razdolnoye reservoir come to feed Grey Heron, Great Cormorant. Flocks of Garganey, Common Teal and Northern Pintail stop during migrations. The presence of field roads and a small distance from the village attract poachers here. Fires in the spring destroy surface vegetation, depriving birds of nesting conditions.

Water sampling was carried out during the low water period in May, July and October 2015-2019 in accordance with GOST R 51592-2000. Macrophytes and sediments were collected in the summer of 2016. Macrophytes were washed with distilled water and dried in a drying Cabinet at a temperature of $50{ }^{\circ} \mathrm{C}$ for 1 hour. Bottom sediments were also dried at $50{ }^{\circ} \mathrm{C}$ for 1 hour. The birds' feathers were selected in the fall of 2019. Sample preparation was carried out on the complex "Temos-Express TE-1", based on the destruction of interfering organic substances by thermal action together with oxidizers $\left(\mathrm{HNO}_{3}, \mathrm{H}_{2} \mathrm{O}_{2}\right)$. Heavy metals in aquatic plants, bottom sediments, and bird feathers were determined by voltammetric method using the STA-1 complex (Tomsk). Heavy metals in the waters of the Arguzikha river were determined by atomic absorption method using the quantum Z. ETA spectrophotometer. Hydrochemical indicators were performed in accordance with federal regulatory documents on nature conservation. 


\section{Research results and discussion}

\subsection{Hydrochemical parameters of river water Arguzikha}

The water temperature in the river corresponded to the hydrological time of year: $9-10{ }^{\circ} \mathrm{C}$ in spring (the third decade of April - the first decade of may), $21-24{ }^{\circ} \mathrm{C}$ in summer (the second decade of may - the second decade of September), 2-4 ${ }^{\circ}$ From autumn (the third decade of September - the first decade of October). The acid-base properties $(\mathrm{pH})$ of the waters of the small Arguzikha river in points I - III were within the norm (4.46 - 8.29) with the exception of autumn water samples in the Razdolnoye reservoir (8.70). In the lower reaches of the river, the $\mathrm{pH}$ value was higher than normal (8.59-9.31). The highest values of water $\mathrm{pH}$ were observed in summer and autumn due to the high biological productivity of phytoplankton. Minimum values of specific electrical conductivity of water were observed in spring, maximum values in summer (table 1). The waters of small rivers in this region are low-mineralized and soft $[2,3]$. The water Color of the Arguzikha river ranged from 22 degrees of color in spring to 115 degrees of color $(\mathrm{Cr}-\mathrm{Co})$ in summer, the maximum value of color was observed in the water of the Razdolnoye reservoir in spring-172 degrees of color. The color of water depends on the type of soil, the content of iron and manganese compounds in the water.

Table 1. Electrical conductivity, $\mathrm{pH}$ and color of the waters of the small river Arguzikha.

\begin{tabular}{|c|c|c|c|c|c|c|c|c|c|}
\hline \multirow[b]{2}{*}{ River } & \multicolumn{3}{|c|}{$\mathrm{pH}$} & \multicolumn{3}{|c|}{$\mathrm{SEC}, \mu \mathrm{S} / \mathrm{cm}$} & \multicolumn{3}{|c|}{ Color$^{\circ}(\mathrm{Cr}-\mathrm{Co})$} \\
\hline & 告 & $\begin{array}{l}\dot{\bar{\Xi}} \\
\stackrel{\Xi}{\Xi} \\
\bar{\Xi}\end{array}$ & 䒠 & $\begin{array}{l}\text { Do } \\
\text { है } \\
\text { के }\end{array}$ & 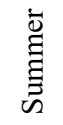 & 䒠 & 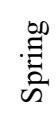 & 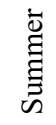 & 䒠 \\
\hline I & 7.46 & 7.89 & 8.20 & 175 & 339 & 231 & 82 & 101 & 27 \\
\hline II & 7.58 & 8.29 & 8.70 & 100 & 124 & 80 & 172 & 51 & 36 \\
\hline III & 7.62 & 7.90 & 7.90 & 171 & 187 & 142 & 80 & 55 & 22 \\
\hline IV & 8.59 & 8.7 & 9.31 & 179 & 190 & 150 & 89 & 115 & 58 \\
\hline
\end{tabular}

Note: The table shows the average values of indicators.

The water of the river Arguzikha contains a large amount of oxygen. The exception is the low oxygen saturation of water $(52 \%)$ in the river below the village of Lermontovka (I) in summer. The river water has high values of permanganate oxidability (PO), which characterizes the high content of organic substances in the water. In the fall, after severe summer floods, the PO value along the entire length of the river decreased. High oxygen saturation of water and high $\mathrm{BOD}_{5}$ values (table 2) in the middle and lower reaches of the Arguzikha river indicate the process of eutrophication.

In spring and summer, $\mathrm{BOD}_{5}$ reached $6.1-13.1 \mathrm{mgO}_{2} / \mathrm{dm}^{3}$ in the middle and lower reaches of the river, and $2 \mathrm{mgO}_{2} / \mathrm{dm}^{3}$ in the upper reaches of the river. In the autumn after the flood, $\mathrm{BOD}_{5}$ in the water of the II and III sections decreased, which is associated with the intensity of self-cleaning processes in the river, and in the I section, on the contrary, increased. Range IV has the highest values of dissolved oxygen in water, $\mathrm{BOD}_{5}$, and $\mathrm{PO}$ during the entire growing season.

Among nitrogen compounds in the water of the Arguzikha river, the dominant position is occupied by ammonium nitrogen, the content of which was especially high in the summer during the rainy season and reached $2.34 \mathrm{mgN}-\mathrm{NH}_{4}^{+} / \mathrm{dm}^{3}$. 
Table 2. Oxygen indicators of the water of the small river Arguzikha.

\begin{tabular}{|c|c|c|c|c|c|c|c|c|c|}
\hline \multirow[b]{2}{*}{ River } & \multicolumn{3}{|c|}{$\begin{array}{c}\text { Dissolved } \\
\text { oxygen, } \\
\mathrm{mgO}_{2} / \mathrm{dm}^{3}\end{array}$} & \multicolumn{3}{|c|}{$\mathrm{BOD}_{5}, \mathrm{mgO}_{2} / \mathrm{dm}^{3}$} & \multicolumn{3}{|c|}{$\mathrm{PO}, \mathrm{mgO} / \mathrm{dm}^{3}$} \\
\hline & 占 & $\begin{array}{c}\dot{\vec{\Xi}} \\
\stackrel{\Xi}{\Xi} \\
\text { ज }\end{array}$ & 声 & 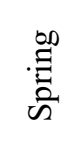 & 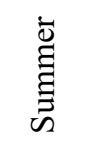 & 总 & $\begin{array}{l}\infty \\
\stackrel{\infty}{0} \\
\text { की }\end{array}$ & $\underset{\Xi}{\stackrel{\Xi}{\Xi}}$ & 恶 \\
\hline I & 8.8 & 4.2 & 13.0 & 2.0 & 1.4 & 7.1 & 15.5 & 14.8 & 6.1 \\
\hline II & 10.8 & 12.9 & 13.6 & 6.8 & 8.2 & 4.0 & 11.7 & 11.2 & 5.8 \\
\hline III & 12.2 & 15.8 & 13.8 & 6.1 & 12.7 & 3.9 & 7.5 & 6.8 & 5.4 \\
\hline IV & 13.2 & 15.9 & 14.6 & 7.9 & 13.1 & 6.1 & 9.35 & 14.9 & 9.9 \\
\hline
\end{tabular}

The concentration of ammonium nitrogen did not meet the standard (MPC $=0.39 \mathrm{mgN}$ $\mathrm{NH}_{4}{ }^{+} / \mathrm{dm}^{3}$ ). Nitrogen compounds entered the water of the river from the surface layers of the soil of agricultural arable land during the flood. In spring, along the entire length of the river, nitrate nitrogen in the amount of $3.45-6.39 \mathrm{mgN}-\mathrm{NO}_{3}{ }^{-} / \mathrm{dm}^{3}$ was detected in the water, which had a pyrogenic origin. Fires cause large concentrations of nitrate nitrogen to appear in water [9]. Authors of works $[10,11]$ name as the reason for the high concentration of nitrogen compounds in river waters leaching of nitrogen fertilizers from agricultural fields, runoff from livestock farms into the river.

The content of nitrite nitrogen in the spring in the water of the Razdolnoye reservoir reached $0.017 \mathrm{mgN}-\mathrm{NO}_{2}{ }^{-} / \mathrm{dm}^{3}$. during the research period, nitrites were detected in other river channels in the amount of $0.002-0.005 \mathrm{mgN}-\mathrm{NO}_{2}{ }^{-} / \mathrm{dm}^{3}$ (table 3). Nitrogen compounds affect the quality of river water during the rainy season, and phosphorus compounds are the main factor in the dry season [12]. Different forms of nitrogen had significant seasonal variations and varied quantitatively in space. In the content of nitrogen compounds, there is a seasonal dynamics: in the autumn, they contain a minimum amount in the water, since nitrates are assimilated by aquatic plants. Nitrogen forms in water are interconnected with physical and chemical parameters in different seasons of the year, with the processes of nitrification and denitrification that occur in rivers [13].

The high content of total phosphorus in the river water was noted in the spring. Phosphates were of pyrogenic origin, since every year grass is burned in floodplains and on agricultural land, and fires occur. Phosphates in bodies of water fall as a result of agricultural activities, because phosphorus is included in fertilizers. In such conditions, affecting the eutrophication of the reservoir, the process of cyanobacteria flowering occurs. Many types of blue-green algae are very toxic and have a harmful effect on human health. Excess phosphorus in the catchment area of the river is carried with the current and is the cause of a serious global water quality problem - eutrophication of the reservoir [14]. A high concentration of total phosphorus indicates hypertrophy of argusi. In the autumn after the flood, the phosphate content in the river was minimal (table 3 ).

The content of cadmium in the river water during the research period did not exceed the norm. In the spring of 2015, the lead content in the lower reaches of the river reached 6.36 $\mu \mathrm{g} / \mathrm{dm}^{3}$, during the subsequent study period, the lead content in the Arguzikha water was less than the MPC. The contents of zinc and copper in the water of the river Arguzikha exceeded the fisheries standard. Maximum concentrations of heavy metals were observed in the lower reaches. The highest concentrations of heavy metals in water were observed in summer. Due to heavy rains and floods, heavy metals were washed out of the surface layers of the soil of agricultural fields and fell into the river. The high content of manganese and iron in the water is due to a natural factor. The formation of the chemical composition of 
natural waters is influenced by soil, rocks, terrain features, climatic conditions, and flooding. The high iron content in the streams of the Amur basin is due to the presence of iron-containing minerals in the soils and rocks of taiga territories. The presence of ferromanganese films and nodules is clearly visible in wetlands. In autumn, the concentration of heavy metals throughout the river decreased (table 4).

Table 3. The content of nutrients in the water of the small river Arguzikha.

\begin{tabular}{|c|c|c|c|c|c|c|c|c|c|}
\hline \multirow[b]{2}{*}{ River } & \multicolumn{3}{|c|}{$\begin{array}{c}\text { Ammonium nitrogen, } \\
\mathrm{mgN}^{-\mathrm{NH}_{4}} / \mathrm{dm}^{3}\end{array}$} & \multicolumn{3}{|c|}{$\begin{array}{l}\text { Nitrate nitrogen, } \\
{\mathrm{mgN}-\mathrm{NO}_{3}}^{-} / \mathrm{dm}^{3}\end{array}$} & \multicolumn{3}{|c|}{$\begin{array}{c}\text { Total phosphorus, } \\
\mathrm{mg} / \mathrm{dm}^{3}\end{array}$} \\
\hline & 足 & 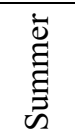 & 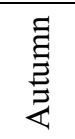 & $\begin{array}{l}\stackrel{\infty}{\Xi} \\
\text { 泀 }\end{array}$ & 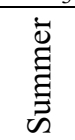 & 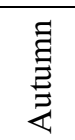 & 告 & 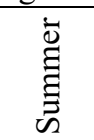 & 声 \\
\hline I & 0.40 & 2.34 & 0.36 & 3.45 & 0.46 & 0.06 & 0.337 & 0.133 & 0.007 \\
\hline II & 0.22 & 1.67 & 0.07 & 4.78 & 0.48 & 0.06 & 0.439 & 0.028 & 0.026 \\
\hline III & 0.13 & 1.61 & 0.06 & 4.01 & 0.49 & 0.06 & 0.476 & 0.048 & 0.004 \\
\hline IV & 0.62 & 2.04 & 0.44 & 6.39 & 0.48 & 0.06 & 0.609 & 0.120 & 0.030 \\
\hline
\end{tabular}

Table 4. The level of heavy metals in the water of the small river Arguzikha, $\mu \mathrm{g} / \mathrm{dm}^{3}$.

\begin{tabular}{|c|c|c|c|c|c|c|}
\hline River & $\mathrm{Pb}$ & $\mathrm{Cd}$ & $\mathrm{Cu}$ & $\mathrm{Zn}$ & $\mathrm{Fe}$ & $\mathrm{Mn}$ \\
\hline $\mathrm{I}$ & $0.95 \pm 0.5$ & $0.11 \pm 0.02$ & $3.7 \pm 1.2$ & $12.8 \pm 1.2$ & $100 \pm 13.9$ & $157 \pm 15$ \\
\hline II & $2.07 \pm 1.1$ & $0.08 \pm 0.05$ & $4.0 \pm 1.2$ & $11.2 \pm 1.2$ & $250 \pm 30.2$ & $443 \pm 31$ \\
\hline $\begin{array}{l}\text { III } \\
\text { IV }\end{array}$ & $\begin{array}{l}1.18 \pm 0.9 \\
3.67 \pm 1.1\end{array}$ & $\begin{array}{l}0.11 \pm 0.1 \\
0.16 \pm 0.2\end{array}$ & $\begin{array}{c}2.0 \pm 0.2 \\
12.44 \pm \\
1.2\end{array}$ & $\begin{array}{c}9.3 \pm 1.0 \\
18.83 \pm 2 . \\
1\end{array}$ & $\begin{array}{c}150 \pm 18.2 \\
640 \pm 64\end{array}$ & $\begin{array}{l}183 \pm 18 \\
230 \pm 23\end{array}$ \\
\hline $\mathrm{MPC}_{\mathrm{f}-\mathrm{r}}$ & 6 & 5 & 1 & 10 & 100 & 10 \\
\hline $\begin{array}{c}\mathrm{MPC}_{\mathrm{h} .-} \\
\text { d.c.-p }\end{array}$ & 10 & 1 & 1000 & 1000 & 300 & 100 \\
\hline
\end{tabular}

Note: $\mathrm{MPC}_{\text {f-r }}$ is the maximum permissible concentration of fisheries, $\mathrm{MPC}_{\text {h.-d.c.p }}$ is the maximum allowable concentration of household and drinking and cultural purposes.

\subsection{Heavy metal Content in the bottom sediments of the Arguzikha river}

The final link in the cycle of technogenic elements in the landscape is the bottom sediments of reservoirs. Accumulation of pollutants in bottom sediments may cause secondary contamination of reservoirs. Therefore, the accumulation of heavy metals in bottom sediments is actively studied [15-17]. The level of heavy metals in the bottom sediments of the small river Arguzikha decreases in the series: $\mathrm{Fe}>\mathrm{Mn}>\mathrm{Zn}>\mathrm{Cu}>\mathrm{Pb}>\mathrm{Cd}$ (Table 5). The level of cadmium, lead, copper and zinc in the bottom sediments of small rivers does not exceed background values. The background is the level of heavy metals in uncontaminated bottom sediments of lakes in Muravyovsky Park [18]. Low content of heavy metals was observed in the bottom sediments of the Arguzikha river in the summer of 2016.

Table 5. The level of heavy metals in bottom sediments of the small river Arguzikha, mg/kg.

\begin{tabular}{|c|c|c|c|c|c|c|}
\hline River & $\mathrm{Pb}$ & $\mathrm{Cd}$ & $\mathrm{Cu}$ & $\mathrm{Zn}$ & $\mathrm{Fe}$ & $\mathrm{Mn}$ \\
\hline Arguzikha & $5.2 \pm 1.6$ & $0.11 \pm 0.03$ & $28.8 \pm 2.8$ & $32.1 \pm 0.3$ & $9090 \pm 270$ & $184 \pm 55$ \\
\hline $\begin{array}{c}\text { Background } \\
\text { values }\end{array}$ & $6-10$ & $0.1-0.3$ & $3-13$ & $28-78$ & & $125-900$ \\
\hline
\end{tabular}




\subsection{The Content of heavy metals in macrophytes of the river Arguzikha}

Water plants for birds are a habitat and shelter from predators. Birds use rdests, duckweed, seeds, rhizomes, and young shoots of macrophytes for food, so the accumulation of heavy metals in aquatic plants creates a risk of exposure to pollutants on birds. A very important task was to study the content of heavy metals in hydrophytes. Nymphoides peltata is a very decorative aquatic plant that takes root with a creeping underwater rhizome, included in the Red books of various regions of Russia. Myriophyllum spicatum is a hydrophyte submerged and floating in the water column. The content of heavy metals in macrophytes of the river Arguzikha decreases in a row: $\mathrm{Fe}>\mathrm{Mn}>\mathrm{Pb}>\mathrm{Zn}>\mathrm{Cu}>\mathrm{Cd}$ (table 6). Macrophytes of the Arguzikha river contained a deficient concentration of copper $(2-5 \mathrm{mg} / \mathrm{kg})$, normally cadmium and zinc. Toxic concentrations of lead $(>30 \mathrm{mg} / \mathrm{kg})$ and manganese $(>300$ $\mathrm{mg} / \mathrm{kg}$ ) were found in macrophytes of Nymphoides peltata and Myriophyllum spicatum L. (table 6). The toxic effect of lead on plants is associated with a violation of fundamental biochemical processes - photosynthesis, mitosis, growth. The most typical manifestation of the toxic effects of manganese is ferruginous chlorosis [4].

Table 6. The average level of heavy metals in aquatic plants of the small river Arguzikha, mg / $\mathrm{kg}$.

\begin{tabular}{|l|c|c|c|c|c|c|}
\hline \multicolumn{1}{|c|}{ Macrophyte } & $\mathrm{Pb}$ & $\mathrm{Cd}$ & $\mathrm{Cu}$ & $\mathrm{Zn}$ & $\mathrm{Fe}$ & $\mathrm{Mn}$ \\
\hline $\begin{array}{l}\text { Nymphoides } \\
\text { peltata } \\
\text { (S.G.Gmel.) } \\
\text { O.Kuntze }\end{array}$ & $35.0 \pm 3.5$ & 0.002 & $2.0 \pm 0.2$ & $31.0 \pm 3$ & $786 \pm 79$ & $536 \pm 53$ \\
\hline $\begin{array}{l}\text { Eleocharis } \\
\text { ussuriensis } \\
\text { Zinserl. }\end{array}$ & $12 \pm 1.2$ & 0.001 & $8 \pm 0.8$ & $9.0 \pm 0.9$ & $380 \pm 4$ & $140 \pm 14$ \\
\hline $\begin{array}{l}\text { Myriophyllum } \\
\text { spicatum L. }\end{array}$ & $30.5 \pm 3.2$ & 0.006 & $2.5 \pm 0.5$ & $\begin{array}{c}29.3 \pm 1 . \\
1\end{array}$ & $658 \pm 66$ & $422 \pm 42$ \\
\hline
\end{tabular}

K. Peng and colleagues (2008), studying the content of heavy metals in macrophytes Potamogeton pectinatus L. and Potamogeton malaianus Miq. rivers of a large industrial city in China under conditions of man-made pollution, found the following concentrations: $\mathrm{CD} 1.96 \pm 1.13 \mathrm{mg} / \mathrm{kg}$ and $1.85 \pm 1.3 \mathrm{mg} / \mathrm{kg}$, respectively, $\mathrm{Pb} 32.1 \pm 12.2 \mathrm{mg} / \mathrm{kg}$ and $15.5 \pm 7.36$ $\mathrm{mg} / \mathrm{kg}$, Mn $513 \pm 23.7 \mathrm{mg} / \mathrm{kg}$ and $819 \pm 23.1 \mathrm{mg} / \mathrm{kg}, \mathrm{Zn} 71.9 \pm 15.1 \mathrm{mg} / \mathrm{kg}$ and $106 \pm 34.0$ $\mathrm{mg} / \mathrm{kg}, \mathrm{Cu} 32.1 \pm 12.2 \mathrm{mg} / \mathrm{kg}$ and $32.1 \pm 12.2 \mathrm{mg} / \mathrm{kg} . \mathrm{kg}$ [19]. In the macrophyte Hydrilla verticillata ( $\mathrm{L}$. fil.) Royle under conditions of agricultural pollution, the $\mathrm{Pb}$ content was $45.3 \pm 4.5 \mathrm{mg} / \mathrm{kg}, \mathrm{Zn} 137 \pm 14 \mathrm{mg} / \mathrm{kg}, \mathrm{Cu} 17 \pm 1.7 \mathrm{mg} / \mathrm{kg}, \mathrm{Mn} 8050 \pm 805 \mathrm{mg} / \mathrm{kg}$ [3]. Submerged hydrophytes can accumulate heavy metals in large quantities. The content of $\mathrm{Zn}, \mathrm{Cu}, \mathrm{Mn}$ and $\mathrm{Pb}$ in macrophytes depends on the content of these elements in water and bottom sediments $[3,19]$.

\subsection{Heavy metal Content in bird feathers}

Birds are at the top of the food chain, widespread, long-lived, sensitive to changes in the environment, accumulate pollutants, so they are bioindicators of environmental pollution. The accumulation of pesticides and organic pollutants in birds is actively studied [20-22]. The content of heavy metals is studied in various organs and tissues of birds - in the blood, liver and muscles, and bones of birds [21,23]. A non-invasive way to obtain information is to detect heavy metals in eggshells and bird feathers [24, 25]. There are recommendations for use in monitoring the environment of Chicks and birds of the first year of life, especially if they are migratory birds [22]. However, adult birds can be used for environmental monitoring $[21,24]$. Researchers pay attention to the study of various types of birds. Birds 
of prey are an important indicator of heavy metal pollution due to their high trophic level [25]. To monitor local environmental pollution, passerines are successfully used, since this is the most numerous order of birds. These birds differ significantly in appearance, lifestyle, habitat conditions, and methods of food production [8]. Current research works are studies on the determination of heavy metals in the habitat of birds of wetlands that are threatened with extinction [24, 26, 27], waterfowl [28].

Heavy metals accumulate during feather growth and contact with the environment. For some chemicals, concentrations measured in feathers may differ significantly from concentrations in tissues and organs. There are differences between concentrations in different types of feathers and internal tissues of birds for different classes of pollutants [25]. Different types of contour feathers differed greatly in their content of heavy metals, in particular lead. Downy feathers have been studied as an alternative biomonitoring [29]. You can collect feathers during molting, but the issue of external contamination is of great concern. Feathers do not always reflect the actual concentrations of pollutants in the bird's body, but can be used to record man-made loads in the bird's habitat. The content of heavy metals in bird feathers often indicates exogenous contamination [30]. The microelement composition of plumage depends on the place of permanent or temporary residence of birds. By the content of heavy metals in the plumage of birds, you can determine the nesting or wintering place of an individual. The bird's feather contacts the circulatory system during growth. In this case, to determine endogenous contamination, the feathers must be thoroughly washed before the study and special training should be carried out. Feathers should be stored in conditions that are protected from potential sources of contamination and degradation (light, moisture) before research [31].

Table 7. Heavy metal concentration in bird feathers, $\mathrm{mg} / \mathrm{kg}$.

\begin{tabular}{|c|c|c|c|c|c|c|c|c|c|}
\hline Name & $\mathrm{Pb}$ & $\mathrm{Cd}$ & $\mathrm{Zn}$ & $\mathrm{Cu}$ & $\mathrm{Fe}$ & $\mathrm{Mn}$ & $\mathrm{Co}$ & $\mathrm{Ni}$ & $\mathrm{Cr}$ \\
\hline $\begin{array}{l}\text { Northern Pintail Anas } \\
\text { acuta (Linnaeus, 1758) }\end{array}$ & $\begin{array}{l}2 \\
0 \\
0+1 \\
\\
\\
\end{array}$ & $\frac{n}{0}$ & $\begin{array}{l}0 \\
0 \\
+ \\
\\
0 \\
0\end{array}$ & 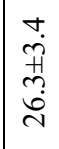 & $\begin{array}{l}0 \\
\dot{0} \\
\dddot{\#} \\
\ddot{H} \\
\ddot{\infty}\end{array}$ & $\begin{array}{c}\tilde{H} \\
\tilde{H} \\
\alpha \\
\dot{+}\end{array}$ & 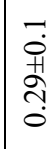 & $\begin{array}{l}\stackrel{+}{0} \\
\stackrel{+}{+} \\
\stackrel{i}{i}\end{array}$ & $\begin{array}{r}\dot{0} \\
\dot{+} \\
\dot{n}\end{array}$ \\
\hline $\begin{array}{l}\text { Garganey } \\
\text { Anas querquedula } \\
\text { (Linnaeus, 1758) }\end{array}$ & $\begin{array}{c}- \\
0 \\
+1 \\
\sim \\
\end{array}$ & $\begin{array}{l}\infty \\
0 \\
0\end{array}$ & $\begin{array}{l}\hat{\sigma} \\
\dot{H} \\
\stackrel{0}{0}\end{array}$ & $\begin{array}{l}\stackrel{+}{i} \\
\text { Hु } \\
\text { id } \\
\text { ñ }\end{array}$ & $\begin{array}{l}\sim \\
\sim \\
\dddot{y} \\
\frac{1}{\infty}\end{array}$ & 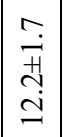 & $\begin{array}{l}\infty \\
\stackrel{0}{0} \\
\text { +1 } \\
\text { ? } \\
0\end{array}$ & $\hat{m}$ & 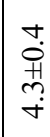 \\
\hline
\end{tabular}

The feathers of the Northern Pintail Anas acuta and Garganey Anas querquedula waterfowl of the Argusikha river contained iron, copper and zinc in the largest quantities, and cobalt and cadmium in the smallest. The content of heavy metals in the feathers of birds decreased in a row $\mathrm{Fe}>\mathrm{Zn}>\mathrm{Cu}>\mathrm{Pb}>\mathrm{Mn}>\mathrm{C} \Gamma>\mathrm{Ni}>\mathrm{Co}>\mathrm{Cd}$. The ratio of elements that has developed during the evolution of the biosphere is due to the biological role of elements and geochemical conditions of the environment. High lead content was found in waterfowl feathers (table 7). The presence of heavy metals in the feathers of birds inhabiting the river reservoir Arguzikha, testified about exogenous contamination.

\section{Conclusions}

The river water Arguzikha are characterized by high oxygen saturation. High oxygen content and high BPC5 values in the middle and lower reaches of the Arguzikha river indicate the process of eutrophication. In spring and summer, high values of permanganate 
oxidability (PO) were observed, which characterizes the high content of organic substances in water. In the fall, after severe summer floods, the PO value along the entire length of the river decreased. The high content of phosphates and nitrates found in spring samples had pyrogenic origin. In summer, the river water contained the largest amount of ammonium nitrogen, which was introduced into the river from the surface layers of soil during rains. The lowest concentrations of nitrogen and phosphorus compounds were after the flood in autumn.

The content of cadmium in the water of the Arguzikha river did not exceed the standard. In the spring of 2015, the lead content in the lower reaches of the river reached 6.36 $\mu \mathrm{g} / \mathrm{dm}^{3}$, during the subsequent study period, the lead content in the Arguzikha water was less than the MPC. Macrophytes contained high concentrations of lead and manganese. In the feathers of waterfowl the content of heavy metals decreased in a row: $\mathrm{Fe}>\mathrm{Zn}>\mathrm{Cu}>\mathrm{Pb}>\mathrm{Mn}>\mathrm{C}>>\mathrm{Ni}>\mathrm{Co}>\mathrm{Cd}$. The elements found in bird feathers were of external origin. The results obtained in a small river Arguzikha is an important step for the study of anthropogenic load on small rivers Zeya-Bureya plain. They are necessary for developing solutions for environmental protection and efficient land use, and the use of environmentally friendly technologies in agriculture.

\section{References}

1. V. I. Radomskaya, S. M. Radomsky, N. G. Kuimova, G. A. Gavrilova and D. V. Putintsev Heavy Metals in the Landscape Components of the South of the Zeya-Bureya Plain, Siberian environmental journal, 6 (15) 841-849 (2008)

2. A. P. Pakusina, Tsarkova M F, T. P. Platonova and T. P. Kolesnikova Chemical and microbiological characteristics of the agrolandscape Zeya-Bureya plain small river, IOP Conf. Series: Earth and Environmental Science, 421, 052003 (2020) doi:10.1088/1755-1315/421/5/052003

3. A. P. Pakusina, T. P. Platonova and S. A. Lobarev The Impact of Land Use on Heavy Metal Pollution of the Small Gilchin River of Zeya-Bureya Plain, Russia Ekoloji, 28 (108), 2693-2704 (2019)

4. A. Kabata-Pendias and H. Pendias Trace elements in soils and plants, 403 (2001)

5. M. A. O. Leguizamo, W.D. F. Gomez and M. C. G. Sarmiento Native herbaceous plant species with potential use in phytoremediation of heavy metals, spotlight on wetlands, A review Chemosphere, 168, 1230-1247 (2017) doi:10.1016/j.chemosphere.2016.10.075

6. A. O. Ekperusi, F. D. Sikoki and E. O. Nwachukwu Application of common duckweed (Lemna minor) in phytoremediation of chemicals in the environment: State and future perspective Chemosphere, 223, 285-309 (2019) https://doi.org/10.1016/j.chemosphere.2019.02.025

7. E. Jaramillo, N. A. Lagos, F. Labra, E. Paredes, E. Acuna, D. Melnick, M. Manzano, C. Velasquez and C. Duarte Recovery of black-necked swans, macrophytes and water quality in a Ramsar wetland of southern Chile: Assessing resilience following sudden anthropogenic disturbances, Science of The Total Environment, 628-629, 291-301 (2018) https://doi.org/10.1016/j.scitotenv.2018.01.333

8. J. D. Wenzhi, Y. S. Wang, H. Zhang, Y. Yang, X. Bao and Y. Zhang Effects of environmental metal pollution on reproduction of a free-living resident songbird, the tree sparrow (Passer montanus), Science of The Total Environment, 721, 137674 (2020) https://doi.org/10.1016/j.scitotenv.2020.137674 
9. V. P. Shesterkin and N. M. Shesterkina Catastrophic Forest Fire Impact on the Water Chemical Composition in the Anuy River Basin, North Sikhote-Alin, Bulletin of the North-Eastern scientific center of the Feb RAS, 2, 47-54 (2016)

10. Y. Yong, C. H. Guang, Y. S. Tian and H. F. Hua Integrated assessment of non-point source pollution in Songhuajiang River Basin, Scientia Geographica Sinica, 27, 231-236 (2007)

11. Y. Yuhong, Y. Baixing and S. Wanbin Assessment of point and nonpoint sources pollution in Songhua River Basin, Northeast China by using revised water quality model, Chinese geographical science, 20 (1), 30-36 (2010) doi: 10.1007/s11769-010-0030-3

12. J. Wang, Z. Fu, H. Qiao and F. Liu Assessment of eutrophication and Water quality in the estuarine area of Lake Wuli, Lake Taihu, China, Science of the Total Environment, 650, 1392-1402, (2019) https://doi.org/10.1016/j.scitotenv.2018.09.137

13. H. Bu, W. Meng and Y. Zhang Nitrogen pollution and source identification in the Haicheng River basin in Northeast China, Science of the Total Environment, 409, 3394-3402 (2011) https://doi.org/10.1016/j.scitotenv.2011.05.030

14. J. O. Goyett, E. M. Bennett and R. Maranger Low buffering capacity and slow recovery of anthropogenic phosphorus pollution in watersheds, Nature Geoscience, 11, 921-925 (2018) doi: 10.1038/s41561-018-0238-x

15. D. M. Polyakov and I. V. Utkin 2018 Accumulation of Subcolloidal Fraction Elements of Bottom Sediments in Amur Bay (Sea of Japan), Oceanology, 58(6), 900-908 (2018) https://doi.org/10.1134/S0001437018070044

16. Z. Wang, L. Yao, G. Liu and W. Liu Heavy Metals in Water, Sediments and Submerged Macrophytes in Ponds around the Dianchi Lake, China, Ecotoxicology and Environmental Safety, 107, 200-206 (2014)

https://doi.org/10.1016/j.ecoenv.2014.06.002

17. M. V. Gapeeva,V. V. Zakonnov,R. A. Lozhkina,D. F. Pavlov and M. Ya. Borisov Heavy metals pollution assesment of underpopulated regions using the example of the north-western region of Russia Human Ecology (Russian Federation), 3, 4-9 (2018) doi: 10.33396/1728-0869-2018-3-4-9

18. A. P. Pakusina, T. P. Platonova and S. A. Lobarev and S. M. Smirenski Chemical and Ecological Characteristics of Lakes Located in the Muraviovka Park, Asian Journal of Water Environment and Pollution, 15(4), 27-34 (2018) doi: 10.3233/AJW-180054

19. K. Peng, C. Luo, L. Lou, X. Li and Z. Shen Bioaccumulation of heavy metals by the aquatic plants Potamogeton pectinatus L. and Potamogeton malaianus Miq. and their potential use for contamination indicators and in wastewater treatment, Science of the Total Environment, 392, 22-29 (2008) doi:10.1016/j.scitotenv.2007.11.032

20. V. Yu. Tsygankov, M. D. Boyarova, O. N. Lukyanova, N. K. Khristoforova Bioindicators of Organochlorine Pesticides in the Sea of Okhotsk and the Western Bering Sea, Arch Environ Contam Toxicol, 73, 176-184 (2017) doi: 10.1007/s00244017-0380-2

21. N. B. Svendsen, D. Herzke, M. Harju, C. Bech, G. W. Gabrielsen and V. L. Jaspers Persistent organic pollutants and organophosphate esters in feathers and blood plasma of adult kittiwakes (Rissa tridactyla) from Svalbard - associations with body condition and thyroid hormones, Environ Res, 164, 158-164 (2018) https://doi.org/10.1016/j.envres.2018.02.012

22. I. Eulaers, A. Covaci, D. Herzke, M. Eens, C. Sonne, T. Moum, L. Schnug, S. A. Hanssen, T. V. Johnsen, J. O. Bustnes and V. L. Jaspers A first evaluation of the usefulness of feathers of nestling predatory birds for non-destructive biomonitoring of 
persistent organic pollutants, Environment International, 37 (3), 622-630 (2011) https://doi.org/10.1016/j.envint.2010.12.007

23. H. Mukhtar, C-Y. Chan, Y-P. Lin and C-M. Lin Assessing the association and predictability of heavy metals in avian organs, feathers, and bones using crowdsourced samples, Chemosphere, 252, 126583 https://doi.org/10.1016/j.chemosphere.2020.126583

24. J. Luo, Y. Ye, Z. Gao, Y. Wang and W. Wang Characterization of Heavy Metal Contamination in the Habitat of Red-Crowned Crane (Grus japonensis) in Zhalong Wetland, Northeastern China, Bull Environ Contam Toxicol, 93, 327-333 (2014) doi: 10.1007/s00128-014-1331-5

25. S. Espin, A. J. Garcia-Fernandez, D. Herzke, R. F. Shore, B. Hattum, E. MartinezLopez , M. Coeurdassier, Tracking pan-continental trends in environmental contamination using sentinel raptors-what types of samples should we use?, Ecotoxicology, 25 (4), 777-801 (2016) doi: 10.1007 / s10646-016-1636-8

26. F. Rahman, A. Ismail, H. Omar, M. Z. Hussin Exposure of the endangered Milky stork population to cadmium and lead via food and water intake in Kuala Gula Bird Sanctuary, Perak, Malaysia, Toxicology Reports, 4, 502-506 (2017) http://dx.doi.org/10.1016/j.toxrep.2017.09.003

27. H. Tereoka, H. Miyagi, Y. Haraguchi, K. Takase, T. Kitazawa and J. Noda Contamination Status of Seven Elements in Hooded Cranes Wintering in South-West Kyushu, Japan: Comparison with Red-Crowned Cranes in Hokkaido, Japan, Archives of Environmental Contamination and Toxicology, 75 (4), 557-565 (2018) https://doi.org/10.1007/s00244-018-0541-y

28. C. Plessl, P. Jandrisits, R. Krachler, B. K. Keppler, F. Jirsa Heavy metals in the mallard Anas platyrhynchos from eastern Austria, Science of The Total Environment, 580 (15), 670-676 (2017) https://doi.org/10.1016/j.scitotenv.2016.12.013

29. L. Monclus, M. Lopez-Bejar, J. D. Puente, A. Covaci and V. L. Jaspers First evaluation of the use of down feathers for monitoring persistent organic pollutants and organophosphate ester flame retardants: a pilot study using nestlings of the endangered cinereous vulture (Aegypius monachus), Environ Pollut, 238, 413-420 (2018) https://doi.org/10.1016/j.envpol.2018.03.065

30. F. Borghesi, E. Dinelli, F. Migani, A. Bechet, M. Rendon-Martos, J. A. Amat. S. Sommer and M. A. Gillingham Assessing environmental pollution in birds: a new methodological approach for interpreting bioaccumulation of trace elements in feather shafts using geochemical sediment data Methods Ecol Evol, 8, 96-108 (2017) doi: $10.1111 / 2041-210 X .12644$

31. V. L. B. Jaspers, A. Covaci, D. Herzke, I. Eulaers and V. Eens Bird feathers as a biomonitor for environmental pollutants: Prospects and pitfalls TrAC, Trends in Analytical Chemistry, 118, 223-226 (2019) https://doi.org/10.1016/j.trac.2019.05.019 